\title{
Pandora's editorial box
}

When David Cervi and Ruth Wajnryb sent me the article that opens this issue, they were not sure if it would be right for $E T$. It might not be of wide enough interest and, since they were tyros in the business of editing journals, they might be saying too much too soon.

However, I welcomed the article. They are certainly new to editing and the article is certainly in the lighter vein, but the issues it addresses are neither ill-timed nor light. Rather, they are the perennial issues of academic editing for such subjects as English. For Wajnryb and Cervi, though the role is seductive, the editorial chair is often uncomfortable. Readers with experience in editing will, I suspect, nod as they read - sometimes ruefully. Some readers may also feel, as I do, that this is just the tip of an iceberg. Beyond formal editing lies the basic communal process of turning draft texts into public statements: composing, revising, criticizing, and re-writing, all of which involve choice of language, style, usage, and presentational conventions.

Since 1987 I have been engaged in two quite different editorial exercises. I have been working on both $E T$ and The Oxford Companion to the English Language, now completed. It is over 800,000 words long, has some thousands of entries from $A$ to $Z$, and was produced by around 100 contributors from all over the world. For $E T$, the aim has been to edit lightly, and 'let a thousand flowers bloom' (within reason). For OCELang, the need has been to create a homogeneous text full of information and opinion, in which contributors' often passionately defended differences of approach, usage and terminology have been subordinated to the creation of a text whose style sits midway between the narrowly academic and the broadly popular. Often I've worked on ET and OCELang on the same day. Often I've caught myself editing ET like OCELang and $O C E L$ ang like $E T$, and had to start again.

In ET22 (Apr 90), David Crystal outlined how he put the Cambridge Encyclopedia together; in this issue, the creation of the EA Foumal is described. Further comment would be welcome on the roles, attitudes, and feelings of editors and editees, critics, reviewers, teachers of writing, and actual and would-be censors, as well as the usage that results from the decisions and comments they make. This Pandora's box may well be worth opening.

Tom McArthur

The editorial policy of English Today is to provide a focus or forum for all sorts of news and opinion from around the world. The points of view of individual writers are as a consequence their own, and do not reflect the opinion of the editorial board. In addition, wherever feasible, ET generally leaves unchanged the orthography (normally British or American) and the usage of individual contributors, although the editorial style of the joumal itself is that of Cambridge University Press.

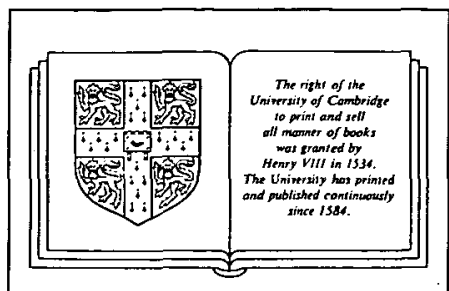

(C) Cambridge University Press 1991. No contents may be reproduced by any means without the permission of Cambridge University Press.

\section{ISBN 0521405882}

English Today (ISSN 0266-0784) is a quarterly.

Publisher: Cambridge University Press, Edinburgh Building,

Shaftesbury Road, Cambridge CB2 2RU. Telephone (0223) 312393

Subscriptions: the current annual subscription price for four issues for libraries and institutions is $£ 38$ outside North America; §18 for individuals; $£ 14$ for students and the retired; airmail $\mathrm{E} 9$ per year extra. Apply to Jane Crossland at the above address.

Advertising Sales: write to Anita Fern at the above address.

\section{USA AND CANADA:}

Publisher: Cambridge University Press, 40 West 20th Street, New

York, NY 10011-4211.

Telephone (212) 9243900.

Subscriptions: the current annual subscription price in USA and Canada for libraries and institutions is $\$ 63 ; \$ 29$ for individuals; $\$ 20$ for students and the retired. Copies are air-freighted to New York to arrive with minimum delay. Apply to Lynda DiCaprio at the above address.

Second class postage paid at New York, NY and at additional mailing offices.

POSTMASTER: send address changes in USA and Canada to English Today, Cambridge University Press, 110 Midland Avenue, Port Chester, New York, NY 10573-9864

Advertising Sales: write to Michelle Alumkal at the above address.

Letters to the Editor: write to Dr Tom McArthur, Editor, English Today, 22-23 Ventress Farm Court, Cherry Hinton Road, Cambridge CB1 4HD, UK.

Typeset by Goodfellow \& Egan Printed in Great Britain at the University Press, Cambridge 